\title{
シンポジウム記録 水産資源管理の国際協力
}

\section{N-1. マーケットの視点を取り入れた 水産資源管理}

\author{
綿貫尚彦 \\ OAFIC 株式会社
}

$\mathbb{N}-1$. Fisheries resource management from the viewpoint of marketing

NAOHIKO WATANUKI

OAFIC Co., Ltd., Chiyoda, Tokyo 101-0048, Japan

\section{1. 水産資源管理協力の変遷}

1990 年代から 2000 年代初頭までは, 調查船による 水産資源調查の協力が中心であったが，2003 年以降は 水産資源管理の生物的側面, 社会的側面, 経済的側面, 人間的側面のバランスに配慮した住民参加型の資源管理 に関する協力が行われるようになった。住民だけではな く, 行政・研究機関さらには産業界が参画する「共同管 理」も実施されている。また，併せて水産資源管理によ る減収をカバーするための代替収入源創出も行われてい る。水産資源管理に関する日本の国際協力は，その現場 力，発想力，実行力が高く評価される一方で，ともすれ ば川上（生産者側）にのみスポットが当てられていると の指摘もある。それに応えるべく, 2014 年頃より, 川 下 (流通・消費者側), つまりマーケットの視点を取り 入れた水産資源管理の試みが始まっている。

\section{2. マーケットの視点が重要な理由}

主な理由を 4 つ挙げる。(1)水産資源管理にマーケッ 卜を巻き込まないと, 乱獲や違法操業がなくならない傾 向がある。例えば法令で禁漁や未成熟個体の捕獲禁止を 定めても, マーケットが魚を求める限り, 漁民は魚を獲 り続ける。(2)マーケットが持続可能な漁業で獲られた水 産物にこだわれば，漁民は資源管理に参加せざるを得な くなる。(3)マーケットに対する水産物の安定供給を図る ためには，魚を減らさない努力が求められる。(4)マ一 ケットが求める水産物の品質・衛生管理に対応できれ ば，付加価值向上（魚価アップ）が期待できる。水産資
源管理が厳しくなればなるほど，漁民の収入が減る。そ うならないように，マーケットと手を携えて，水産物の 価値をアップさせることが必要である。

\section{3. マーケットを念頭に置いた水産資源管理}

セネガルのマダコ漁業を例として取り上げる。川上発 想の水産資源管理を改妓, 川下を含めた全体として見 ていく試みである。プロジェクト（実施中）の目指すと ころは，セネガル産マダコの対日輸出をインセンティブ とした資源管理の促進である。資源管理強化の前に行う べきことはマダコの品質管理であるというスタンスであ る。第一に，輸出先となる日本市場ニーズ（高品質，低 価格, 安定供給, 小型サイズ）の把握を行った。第二 に，水産資源管理に積極的に取り組んでいる複数の漁村 に扔いてマダコの品質管理指導を行い，さらに現地の水 産会社と連携し，商品サンプルを日本に輸出した。第三 に, シーフードショー東京・大阪などのイベントにおい てセネガル産マダコを PR するとともに，バイヤー（イ ンポーター，卸，小売）へのアンケート調査を実施し た。第四に，セネガル企業と日本企業の双方に対し，良 い品質のマダコと悪い品質のマダコで価格差をつけるよ う働きかけた。第五に，マダコ資源管理を促進するため に，(1)バイヤーへの働きかけ（体重 $350 \mathrm{~g}$ 未満の個体の 輸入自主規制)，(2)大手スーパーの環境月間への参加に 関する協議（セネガル産マダコフェア），(3)セネガル政 府への働きかけ（現在の資源管理方策「禁漁期」「産卵 用たこつぼ設置」「体重制限」の修正・強化)，(4)マダコ 資源管理を支援している EU プロジェクトとの連携・ 調整，(5)国際マダコ会議の開催（資源管理に豊富な経験 を持つモロッコ及びモーリタニアとの連携後押し）を 行った。

セネガル産マダコの高品質化はさほど難しくなく，日 本市場における評価も高かったが，魚価は期待ほど上が らなかった。マダコを少しでも高く買わないことには, 漁民の行動は変わらず，良質なマダコの安定した輸出は 実現しない。マーケット側の意識・行動変革を促すこと も重要であると考えられた。 